\title{
Memorialising the Past: Is there an Aboriginal Way?
}

\author{
BRONWYN BATTEN AND PAUL BATTEN
}

Tn Australia, men of European background dominate 1 memorials. This dominance is largely a product of the times in which the majority of memorials were created between 1800 and the post WWII era. ${ }^{1}$ In these times, the focus of history was on politics and warfare both of which were the 'stages' on which the lives of great men were played out. ${ }^{2}$ In the 'postmodern' era, the practice of history has expanded to incorporate not only the 'achievements of great men but of ordinary people, especially those minority or disadvantaged groups supposedly outside the mainstream' ${ }^{3}$ Whilst the study of history has expanded to include minority groups such as Australia's Indigenous people, the field of heritage interpretation is only beginning to engage with diverse perspectives of the Australian past. ${ }^{4}$ Similarly, although there 
has been a growth in memorialisation in recent times, ${ }^{5}$ it is only relatively recently that memorials have begun to engage with the history of minority groups and in particular Indigenous Australians. ${ }^{6}$

The idea of memorialisation is seen by some people as being 'foreign' to Australian Indigenous cultures. This is particularly relevant to the so-called 'European' style of memorialisation generally adopted in Australia that has a classical lineage such as stone and bronze statues, sculptures and pillars. If Indigenous people had memorials it was assumed that places within the landscape itself served the memorial function and thus they were a 'natural' form of memorial.

Despite this, the post-contact Australian past has produced memorials commemorating either the lives of Aboriginal people or events of Aboriginal history. The number of memorials dealing with Aboriginal history has been increasing. As recognition of the shared history between Indigenous and non-Indigenous Australians grows, so too does the desire to memorialise this aspect of the past as well. In recent years, Indigenous and non-Indigenous people have begun to formally memorialise their shared history.

Those who have taken on the task of commemorating Aboriginal history are confronted with the issue of whether the form of memorial they choose is appropriate. This article explores how the Aboriginal past is being memorialised. Firstly, it introduces a multi-faceted example from Botany Bay National Park. Then, by way of response to the issues highlighted in the Botany Bay case study, the article deals with a series of example memorials to engage with the following topics:

- the role of landscape and natural materials in memorialising the Aboriginal past

- cultural evolution and the adoption of so-called 'European' ways of memorialising

- the evolving role of counter and anti-memorials

- shared history memorials, and the role of consultation to ensure Indigenous perspectives are incorporated when nonIndigenous people are the driving force behind the creation of a memorial and

- the role of memorials for Aboriginal people. 
Examples of memorials from around Australia are used to stimulate discussion of the above topics and to reflect on the ways in which people in Australia are choosing to memorialise the Aboriginal past and the issues that they confront in order to do so.

\section{Are Memorial Statues Appropriate to the Aboriginal PASt?}

The Meeting Place Precinct at Botany Bay National Park contains the site where Lieutenant James Cook first set foot on Australian soil in 1770. Because of the links between Cook's voyage and the decision to establish a British colony in New South Wales, the site in Botany Bay National Park is regarded by some as the birthplace of modern Australia. In 2002 a Master Plan was developed for the Meeting Place Precinct. One of the major features within the area is a series of impressive and at times imposing monuments to Cook and the crew of his ship, the Endeavour. These monuments line the foreshore and were mostly built in the early to mid 1900s. In the 2002 Master Plan these monuments, along with a number of other locations within the Meeting Place Precinct, were identified to become interpretative 'nodal points' in a proposed 'Midden to Monument Walk'.

The Master Plan proposed that many of the nodal points should include Indigenous perspectives of Cook's landing and should touch on aspects of pre and post-contact life for the Gweagal, the Indigenous people of the area. The principle behind this interpretation appears to be about portraying the idea that Indigenous people were active players in the history of Australia. One interviewee in a 2003 study on heritage interpretation at Botany Bay National Park noted that most of the proposed interpretive nodes are based at existing monuments with only one or two additional nodes. This effectively means that Indigenous perspectives are included in the walk but they are largely 'only a response to the existing non-indigenous monument'. This may appear to be 'a bit imbalanced as there are only one or two nodal points driven from an Indigenous perspective' ${ }^{8}$ 
One idea that emerged from the consultation process suggested the inclusion of an Indigenous monument in the walk - a 'Two Warriors' statue. The 'Two Warriors' were Gweagal men who stood their ground on the rocks while confronting Cook's landing until shot at several times by the marines. The Master Plan explained that members of the Aboriginal community saw a depiction of the story of the 'Two Warriors' as pivotal, as they felt it would help reconciliation by creating an understanding that 'Aboriginal people did challenge European occupation from the very beginning [and that]... Aboriginal occupation of the region continues today'. ${ }^{9}$

The official draft (consultation) version of the Master Plan, however, included a counter argument, suggesting that a statue of the 'Two Warriors' or another Aboriginal monument should not be incorporated in the 'Midden to Monument Walk'. Whilst the draft plan acknowledged that members from both the Indigenous and non-Indigenous communities had called for an Indigenous monument to be added to the track, it recommended against this suggestion for two reasons:

The placement of additional monuments in the landscape has the potential to negatively affect the site and existing monuments, and must be considered with great caution...

In terms of perceived 'equalisation' of histories via monuments to Aboriginal resistance, it must be considered that 'Aboriginal' monuments would be part of a European tradition, and unacceptable to the integrity of the site. This is also true of the placement of any object attempting to signify 'Aboriginality' through non-traditional means - they must be considered with great caution, but works of art could be placed within the Interpretive Gallery as temporary exhibitions. ${ }^{10}$

Both the draft and final versions of the Master Plan acknowledged the 'gesture of goodwill' by community groups who advocated the addition of an Aboriginal monument but suggested that such a monument was inappropriate. Although 
toned down in the final version of the plan - through the omission of the second paragraph as quoted above - the plan still implies that there are distinctly Aboriginal ways to present heritage. This perspective, as intimated in the following quote, is tied to assumptions of Aboriginality being firmly based in the natural rather than the historic world:

It is recommended that stories with an Aboriginal focus be delivered via audio and signage in the interpretative nodes. This will provide a means whereby Aboriginal people can record their stories and have quotations placed strategically around the site, within the context of as natural a landscape as is possible to provide at this time. ${ }^{11}$

\section{LANDSCAPE AND NATURAL MATERIALS IN}

\section{ABORIGINAL MEMORIALS}

Generally, in Aboriginal worldviews people and culture are seen as an 'integral whole' and there is 'no separation of nature and culture' ${ }^{12}$ It is not surprising therefore that natural forms of memorials such as native gardens, and materials such as wood, water and rocks, can often form a key part of Aboriginal memorials. This is particularly the case with many 'Stolen Generations' memorials around Australia.

The Stolen Generations Memorial which was opened at Mount Annan Botanic Garden in October 2007 is just one of many examples of a memorial 'garden' or a memorial which utilises a natural landscape setting. It is situated within one hectare of forest with boardwalks leading to a sculpture space that contains a work carved from sandstone by the internationally renowned Aboriginal artist Badger Bates. The work aims to highlight 'the tragic consequences of the separation of Aboriginal children from their parents ${ }^{13}$ by government agencies. Bates provides the following description of his work on the Botanic Gardens Trust web site:

The front panel of the sculpture shows a mother and father with small child and baby - the child size footprints on the ground represent the child being taken away, and the adult footprints on the other side 
represent the grown up child returning to find his/her people. The water feature represents the tears of sorrow shed by all affected by the Stolen Generations - tears that are still being shed today. The back panel is my gift to the Stolen Generations. It represents a thundercloud and rain called up by the Ngatyi or Rainbow Serpent, who is angry and sad over the hurt done to his people who were taken away from their country. ${ }^{14}$

According to one review, the natural setting of the memorial helps visitors to 'experience the Memorial as a journey of healing and reflection, as they walk through the forest... [into a] peaceful meeting place with water and a sculpture space. ${ }^{15}$ Beyond this however, the memorial brings a particular sense of peace to Aboriginal people who visit it. The natural forest setting provides an opportunity for reconnection with Country. It is this factor, above all others, which has lead to the proliferation of Aboriginal memorials, particularly Stolen Generation memorials, within a natural setting.

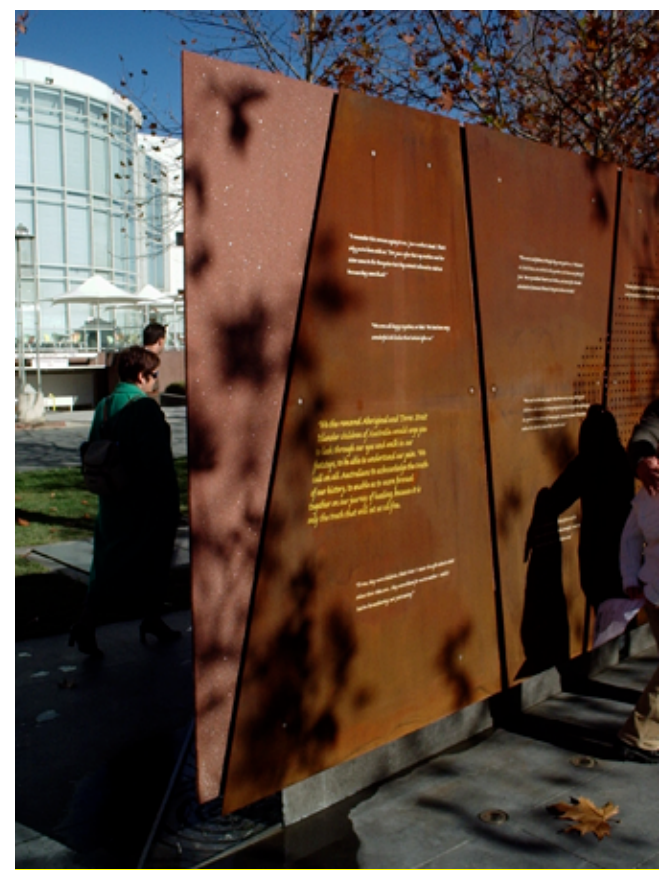

Figure 1 - One of the 'Separation slivers' as it stands today at Reconciliation Place (Photograph Bronwyn Batten) 
The 'Separation slivers', depicting the Stolen Generations at Reconciliation Place in Canberra, provides a counterpoint to memorials utilising natural settings as described above. The overall design of Reconciliation Place came out of a national competition. The chosen design consists of a central grass mound and radiating concrete pathways along which are placed artworks or 'slivers' of glass, stone, steel and red-oxide concrete that carry 'inscriptions and images on various themes and events significant to reconciliation' ${ }^{16}$ The two slithers depicting the Stolen Generations were designed to align to the model of the 'sliver' that the overall design of reconciliation place established. The 'Separation slivers' were thus constructed of glass, red oxide concrete and steel. ${ }^{17}$

The character of the slivers as they stand today did not align with the view of many of the Stolen Generations as to what an appropriate memorial at Reconciliation Place should be. They felt that it should be natural in form, 'such as a garden with running water... a place for quiet reflection' ${ }^{18}$ The lack of consultation early on in the establishment of Reconciliation Place, however, meant that the creators of the Stolen Generations memorial now had to work within the model of the 'slivers' already in place. The question for them became how to represent in a limited number of words and images the experiences of those taken from their families. As the Co-chairs for the National Sorry Day Committee stated: 'The most we can hope for in Reconciliation Place is a sliver or slivers that do not distort the truth of this part of our history. But we do not think such a sliver is an adequate memorial' ${ }^{\prime 19}$

\section{ABORIGINAL MEMORIALS AND THE 'EUROPEAN' FORM}

Although gardens and natural materials are common features of many Aboriginal memorials, there is also a growing trend for Aboriginal people to adopt more classical, 'European' forms of memorials, such as the use of bronze sculptures and statues.

One of the first bronze sculptures created as a memorial to an Aboriginal person is that of Yagan. He was a Nyungar man, and a key figure in leading Nyungar resistance to the colonisation of the Swan River region - near where the towns 
of Perth and Fremantle are today - in the early 1830s. The Nyungar community had lobbied since the early 1970s to have a statue to Yagan erected. ${ }^{20}$ They were unsuccessful in gaining the financial support of the West Australian government but were able to raise the funds over time to commission the Australian sculptor Robert Hitchcock to create a bronze sculpture of Yagan which was completed in 1984. ${ }^{21}$

The statue of Yagan has been the subject of controversy ever since. When the head of Yagan (which was taken to England after his capture and death) was repatriated to the Nyungar community in 1997 the statue was beheaded. Upon the statue's restoration it was beheaded again. The statue, which depicts Yagan naked with a spear, has also been subject to continual comment that it would be more appropriate for the figure to be clothed. The form, however, of the memorial does

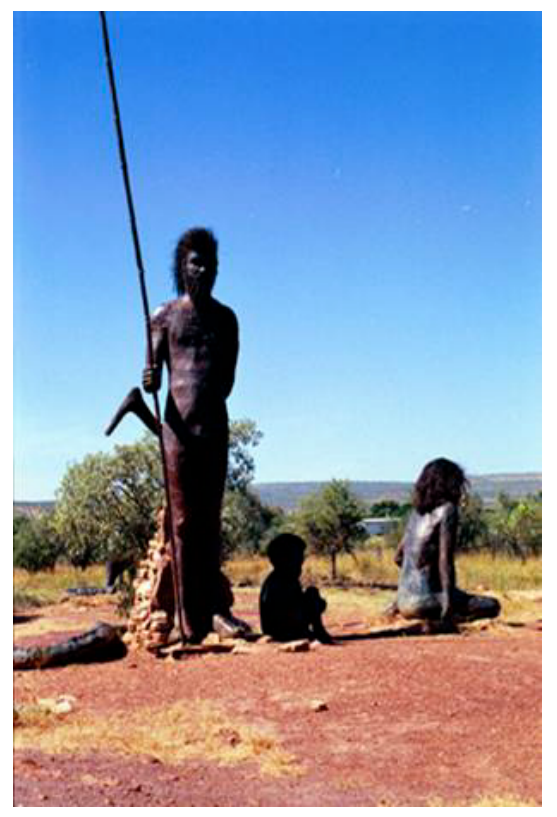

Dreamtime Statues at Warriu Park (Photograph Bronwyn Batten)

not appear to be the cause of controversy. Rather, tensions surround the depiction of a resistance leader and whether, and it what context, such a leader should be presented. Despite these issues, the statue of Yagan represents a significant 
memorial to the Aboriginal past and is arguably the 'bestknown statue of an Aboriginal leader in Australia'. ${ }^{22}$

Another example of an Aboriginal community choosing to use bronze sculptures can be found at Warriu Park in Wyndham, Western Australia. Bronze statues of a three times life-sized Aboriginal family were constructed in 1989 by Joorook Ngarni Aboriginal Corporation to help Wyndham reflect on its Aboriginal past. The plaque underneath the statues reads:

Warriu Park is dedicated to those who prepared us for today. Built by Joorook Ngarni... this monument was presented to the citizens of Wyndham... Aboriginal spirits will always survive in this timeless and beautiful land.

Research from Lawton suggests that this memorial is often interpreted as 'kitsch' - a giant Aboriginal family that is just one more example of something 'big' on the 'circuit' of all things 'big' in Australia (including the Big Banana, the Big Pineapple and the Big Merino). ${ }^{23}$ It is seen by many tourists as just a ploy to attract more visitors to the town and not an authentic 'Aboriginal' expression of attachment to the land. Yet, the memorial itself has a very real place in the hearts of the town's Aboriginal community. As one interviewee in the 2001 study on the town's Aboriginal history and heritage said: 'it is the only significant statement about the past in Wyndham'. ${ }^{24}$ The Aboriginal community have adopted a 'European' way of memorialising the past and the result has significance for that community.

Another more recent bronze sculpture commemorates the life of Sir Douglas Nicholls and his wife, Gladys. Douglas Nicholls was the first Aboriginal footballer to play for Victoria and in his later life became Governor of South Australia. ${ }^{25}$ Douglas Nicholls was also the first Aboriginal man to be knighted. ${ }^{26}$ The memorial was opened in Melbourne's Parliament Gardens in December 2007. It consists of two oneand-a-half times life-sized bronze sculptures of Sir Douglas and Lady Gladys Nicholls by Louis Laumen and an artwork etched into bluestone by Ngarra Murray, Sir Douglas' Great- 
Granddaughter. A description of Murray's artwork, which is titled Dungula Wamayirr - River People - notes that it:

represents the artist's great-grandmother and greatgrandfather's connection to their country. Diamonds depict the traditional markings of their clan groups and their totems, Bigarrumdja the Emu (Yorta Yorta) and Waa the Crow (Dja Dja Wurrung) symbolise their ancestors and their stories. ${ }^{27}$

The Nicholls memorial is 'the first statue of a $20^{\text {th }}$ century Aboriginal leader to be erected anywhere in Australia' ${ }^{28}$

The blending of the two approaches in the Nicholls Memorial - 'traditional' artwork with a classical style of memorial in the bronze sculpture - strikes a balance, evoking Sir Douglas' and Lady Gladys' place in both Indigenous culture and Australia's shared history. Also, the presence of the memorial in Melbourne's Parliament Gardens and the public support given to the memorial by the City of Melbourne - the statue was proposed by the City Council Assets and Services Division $-{ }^{29}$ mean that the memorial is unlikely to ever face the same level of controversy as the memorial to Yagan or that in Warriu Park.

\section{Alternate Voices, COUnTER- AND ANTI-Memorials}

In her research dealing with memorials, Sue-Anne Ware writes that during the 1980s in Australia there was a 'shift away from normative memorial treatment to engage with the strengthening multicultural aspects of Australian society'. In Melbourne, according to Ware, this trend was exemplified in a series of memorial additions or 'tack-ons' ${ }^{30}$ These countermemorials, as they have been termed, offered a way for 'dated memorials to evolve with historical perspectives'.$^{31}$ Plaques could be added to an existing memorial to provide alternate views of history. In addition to incorporating multicultural perspectives of the Australian past, the counter-memorial was also utilised during the 1980s and 1990s to re-interpret Aboriginal history.

Monuments that were offensive, particularly to Indigenous people, have been the target of this style of reinterpretation. ${ }^{32}$ 
The Explorer's Monument, built in 1913, in Fremantle, Western Australia, is an example of a monument that an Aboriginal community found offensive, in this case the Baldja Aboriginal network, a Fremantle Aboriginal group. The main inscription on the monument reads as follows:

This monument was erected by C. J. BROCKMAN As a fellow bush wanderer's tribute to the memory of PANTER, HARDING AND GOLDWYER Earliest explorers after Grey and Gregory of this Terra Incognita, attacked at night by treacherous natives were murdered at Boola Boola near La Grange Bay on the 13th November 1864 Also as an appreciative token of remembrance of MAITLAND BROWN One of the pioneer pastoralists and premier politicians of this State, intrepid leader of the government search and punitive party, his remains together with the sad relics of the ill fated three were recovered at great danger from the lone wilds repose under public monument in the East Perth Cemetery "LEST WE FORGET"

Not only is the text on the plaque offensive - amongst other details describing the Indigenous people as 'treacherous natives' and brushing over the establishment of a 'punitive party' that, by one account, killed 20 innocent men, women, and children. The images on the memorial show Indigenous people chained around the neck.

Provoked by this one-sided representation of Australian history, a Western Australian university initiated a project to examine the origins of the monument and to rewrite the history it portrayed. ${ }^{33}$ The Public Action Project found that 'the monument distorts and disguises the real causes behind the explorers' deaths'.$^{34}$ For example, documentary evidence found by the Public Action Project indicated that the 'killing of Panter and his party may well have been retaliation for the indignities suffered by Aboriginal people' including the desecration of sacred sites, abuse of Indigenous people and other frontier violence. ${ }^{35}$ In response to what they saw as historical inaccuracies, the Public Action Project made a submission to Fremantle City Council in 1988 - Australia's Bicentennial year - 
to include an additional plaque on the monument that would highlight an Aboriginal perspective of the events memorialised.

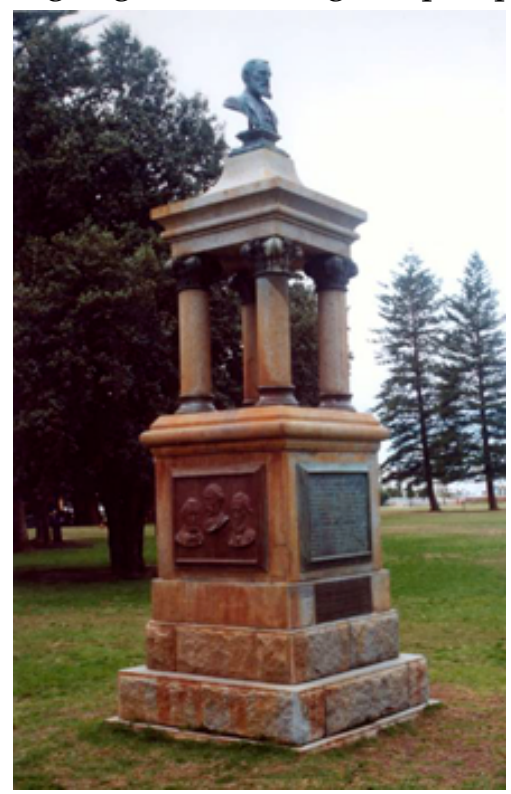

The Explorer's Monument

(Photograph Bronwyn Batten)

The additional plaque ultimately placed on the monument reads:

This plaque was erected by people who found the monument before you offensive. The monument describes the events at La Grange from one perspective only: THE VIEWPOINT OF THE WHITE 'SETTLERS'. No mention is made of the right of Aboriginal people to defend their land or of the history of provocation which led to the explorers [sic] deaths. The punitive party mentioned here ended in the deaths of somewhere around twenty Aboriginal people. The whites were well-armed and equipped and none of their party were killed or wounded. This plaque is in memory of all the Aboriginal people killed at La Grange. It also commemorates all other Aboriginal people who died during the invasion of their country. Lest We Forget. Mapa Jarriya-Nyalaku 
Bulbeck writes that a counter-memorial 'provides a second disjunctural reading for the spectator which the monument does not resolve' and is 'one of the most powerful forms of rewriting memorial history' ${ }^{36}$ Certainly in the case of the Explorer's Monument, these arguments appear well founded.

In terms of the theory of heritage interpretation, Ware, in contrast to Bulbeck, argues that, in the end, counter-memorials are "'band-aids", existing only in relation to representations of a historical "wrong"'. An extra option, Ware suggests, is the anti-memorial. Anti-memorials need not be created in juxtaposition to an existing memorial. They differ further from a counter-memorial in that they denote and even celebrate impermanence, 'thus contradicting the perpetual memorial and established notions of collective memory'. The alternative concept to a traditional memorial is linked to an expanded role for remembrance: 'Anti-memorial design... positions itself as a physical catalyst for social change' ${ }^{37}$

Anti-memorials are beginning to play an important role in commemorating Aboriginal and shared history. Ware provides several examples of anti-memorial concepts from the Victorian Stolen Generation Memorial Competition held in 2001. Several of the entries cited by her were interactive, suggesting that visitors would participate in actions which were either symbolic of the original removal of children or represented reconciliation and the undoing of government policy. For example, one entry suggested involving the public symbolically by replacing turf that had been cut to form words from the Archie Roach song 'Took the children away'. Another entry required the public to remove threads from Hessian fabric printed with government policies related to the Stolen Generation in order to expose a second layer of Hessian underneath to reveal printed stories of the Stolen Generation.

Both these entries, if implemented, would have required public participation to alter their state. Ware argues that it is this transient nature that helps anti-memorials to be disturbing and provocative. ${ }^{38}$ Perhaps, however, Ware overemphasises the importance of transience. As the following section outlines, a permanent memorial can also be a catalyst for social action and 
change, particularly when there is consultation and a sharing between stakeholders.

\section{SHARED MEMORIALS AND CONSUltation}

It is possible for a memorial to represent the interests of more than one group of people. The Myall Creek Memorial in northern New South Wales was created as a shared memorial. Both Indigenous and non-Indigenous people were not only consulted in the creation of the memorial, they were and are active players in that process and in the organisation of ongoing activities related to the memorial. The Myall Creek Memorial Committee was created with representation as a corner-stone. An agreement was reached at the initiation of the memorial project to ensure the make up of the committee consist of equal numbers of Indigenous and non-indigenous members. ${ }^{39}$

The Myall Creek Massacre occurred on 10 June 1838. Peter FitzSimons describes the massacre as one of the 'most tragic and remarkable chapters of Australia's history'. ${ }^{40}$ 'Like many Australians', Fitzsimmons writes in the Foreword to a 2007 dramatised account of the events, 'I had vaguely heard of the "Myall Creek Massacre" but knew nothing of the detail'. ${ }^{41}$ The massacre is in the national consciousness, but at its periphery. John Mulcair observes that:

for the first time in the colony of NSW, where killing Aboriginals to make way for pastoral expansion was perfectly acceptable, the perpetrators of the horror were pursued and tried. Seven of them hanged. ${ }^{42}$

The idea of creating a memorial to the massacre dates back to at least 1965. A local resident tried to gain support to 'erect a memorial which would take the form of a symbolic gate on the site of the massacre' ${ }^{43}$ But it was condemned in a letter writer to a local paper who commented: 'The whole idea was illconceived, unconsidered, mischievous and an insult to the Bingara people. ${ }^{44}$ No memorial was erected at that time. It was not until 1998 that the prospect of a memorial was again seriously raised. In that year, a descendant of one of the Myall 
Creek massacre survivors, Sue Blacklock, organised a reconciliation conference at Myall Creek where a decision was made to erect a permanent memorial. ${ }^{45}$ A committee was formed at the commencement of the project. They consulted

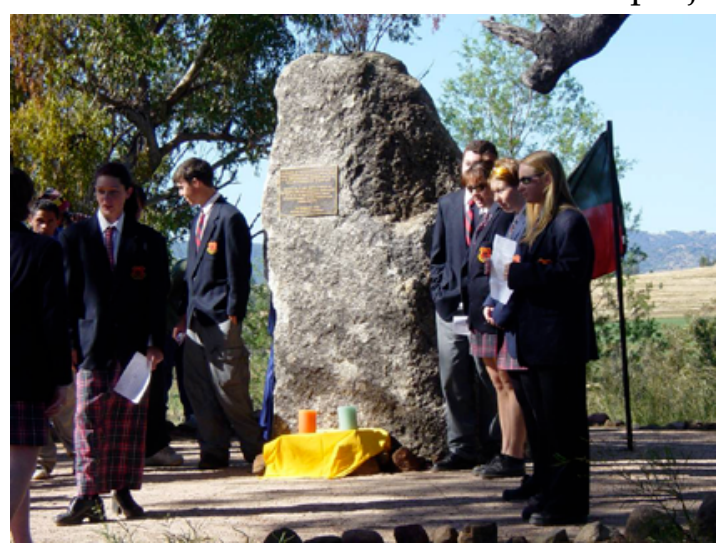

Students at the Final Boulder at the Myall Creek Memorial Ceremony 2003 (Photographer Bronwyn Batten)

descendants of the local Aboriginal people, the Wirrayaraay, as to how the project should continue. ${ }^{46}$ The Wirrayaraay were given the option of continuing the project themselves or of involving both Indigenous and non-Indigenous people. There was unanimous support for it being a jointly managed project. ${ }^{47}$ From that time, the project increasingly took onboard aspects of shared history and reconciliation.

The Myall Creek Memorial was officially unveiled at a memorial ceremony on 10 June 2000. Since then, a memorial ceremony has been held annually on the weekend closest to 10 June. The memorial sits in a rural landscape and consists of a winding path lined along the way with large stones with plaques on them that progressively tell the story of the massacre and its aftermath. The path ends at a large boulder overlooking the Myall Creek Station with a plaque that reads:

In memory of the Wirrayaraay people who were murdered on the slopes of this ridge in an unprovoked but premeditated act in the late afternoon of 10 June, 1838.

Erected on 10 June 2000 by a group of Aboriginal and non-Aboriginal Australians in an act of reconciliation, 
and in acknowledgement of the truth of our shared history.

We remember them. Ngiyani winangay ganunga.

Since its formation in 1998, the Myall Creek Memorial Committee have increasingly promoted the Myall Creek Memorial and the associated annual memorial ceremony as a national symbol of reconciliation. Beyond commemorating the event, the memorial ceremony and the memorial itself are utilised to educate Australians about Australia's collective history. ${ }^{48}$ Just as the creation of the memorial itself was very much a shared Indigenous and non-Indigenous achievement, the Memorial Committee want to see the memorial bring Indigenous and non-Indigenous Australians together.

\section{THE ROLE OF MEMORIALS FOR INDIGENOUS PEOPLE}

The role a memorial plays for Indigenous people is particularly important. The purpose of many memorials that portray the Aboriginal or 'shared' past is to educate the non-Indigenous community about that past. The form of these memorials is often influenced by this purpose, with an educative memorial more likely to adopt a 'European' form and to have accompanying plaques or signage to interpret the wider history that the memorial is reflecting. There are, however, examples of memorials with very different purposes. They exist predominantly for Aboriginal communities to reflect and remember the past and play little or no educative role to noncommunity visitors to that site.

One such example is the Wybalenna historic site on Flinders Island, Tasmania. The primary purpose of this memorial is to provide a place of reflection for the Aboriginal community. The memorial takes the form of a garden and memorial gate. The site is known as the 'Aunty Ida West Healing Garden and Memorial Gate'. Ida West (1919-2003) was the 2002 National Female Aboriginal Elder of the Year. She was a leader of the Tasmanian Aboriginal people or 'Palawa' and a campaigner for the causes of Indigenous people.

Wybalenna historic site holds the memories of a painful history for the Palawa. Between 1831 and 1835 George 
Augustus Robinson brought together what was thought to be the last of the Indigenous people that remained in Tasmania (then called Van Diemen's Land). Robinson relocated the Indigenous people to Pea Jacket Point (Wybalenna). By October 1847 there were only 44 survivors of the original 200. In $1854-$ when only three men, eleven women and two children remained - they were transferred to Oyster Cove, Tasmania, under the care of Superintendent Dr J. Milligan. In 1865, Billy Lane, the last of the men, died and only four women remained. Truginini, the last survivor, died in $1877 .{ }^{49}$

Even though descendants of the Palawa (often they were joint descendants of the Palawa and non-Indigenous people) still survived in various places throughout Tasmania and in particular on the Bass Straight Islands, a dominant perception remained that the Palawa had 'died out'. Ida West was one such descendant of the Palawa. Ida was born on Cape Barren Island, moving to Flinders Island in the 1920s. Ida was a crucial figure in the campaign to return Wybalenna to the Palawa. In 1999, after twenty years of campaigning for its return, Wybalenna was handed back to the Indigenous community. ${ }^{50}$

The 'Aunty Ida West Healing Garden and Memorial Gate' is located next to the chapel at the Wybalenna historic site. The chapel is the only remaining building at what was once Robinson's chosen site for the remaining Palawa to live out their days. Amazingly, such a painful and crucial site to the history of Indigenous and non-Indigenous relations in Australia contains little evidence of the stories and experiences of the Indigenous people who lived there. A card, adorning the Wybalenna chapel door, states:

Built by convicts in 1838 from locally made bricks, this was the focal point of a settlement developed by George Augustus Robinson in an attempt to save the Tasmanian Aborigines from extinction. The settlement was abandoned in 1847 when the few remaining Aborigines were transferred to Oyster Cove, near Hobart. The Furneaux Island Group of the National Trust of Australia (Tasmania) purchased and restored this chapel as a memorial to the lost race. It was opened 
by Sir Stanley Burbury, K.B.E, Governor of Tasmania, on $9^{\text {th }}$ June 1974.

The sign on the door to the chapel, whilst valuable in providing an insight into the historical significance of the building, is invalid in that it is not a memorial to a 'lost race'. If the chapel was reinterpreted, however, it could provide a much needed insight to visitors into Tasmanian Aboriginal history. Wybalenna has the potential to become a site of innovative, interesting and informative interpretation about the Tasmanian past. It has the potential to challenge the still prominent attitude that there are no 'real' Tasmanian Aborigines left.

The 'Aunty Ida West Healing Garden and Memorial Gate' begins to address the Aboriginal significance of the historic site. Currently, all that has been created in the garden next to the chapel is a wooden gate and a table and bench, unveiled by the Tasmanian Premier, Paul Lennon, in April 2004. A plaque on the entrance gate offers an explanation of the purpose of the garden: 'In recognition of Aunty Ida West's contribution to the settlement of Tasmanian Aboriginal People'; 'Healing the past'.

Unfortunately for the visitor, no explanation is given of who Ida West was or any depth of information about her relationship to Wybalenna. But the memorial does provide a sense that this is a significant Aboriginal site and that its history lives on today. This is also aided by an inscription on the table in the garden that says:

It's pretty important you know, the land, it doesn't matter how small, it's something... just a little sacred site... that's Wybalenna. There was a massacre there; sad things there, but we try not to go over that. Where the bad was, we can always make it good - 1995, Aunty Ida West

Both of the plaques provide powerful pieces of writing that make the visitor contemplate the site. Perhaps because the plaques are very personal, and the exact details as to who Ida West was and what she did remain unstated, a feeling of the intimacy Indigenous people still feel for the site today is created. The site, then, is more a memorial for the Palawa and 
their personal attachments to the past, rather than a site where all Australians can learn about Tasmania's Aboriginal history.

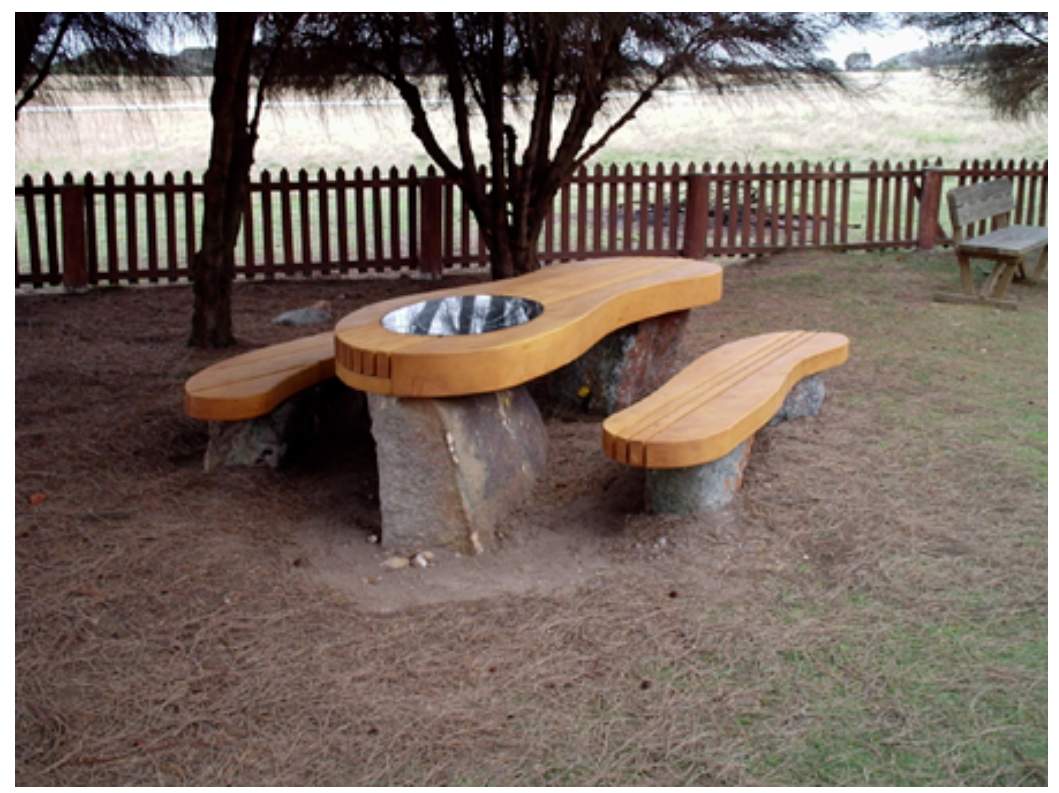

Above: Table in the Aunty Ida West Healing Garden; below Aunty Ida West Memorial Gate (Photographer Bronwyn Batten)

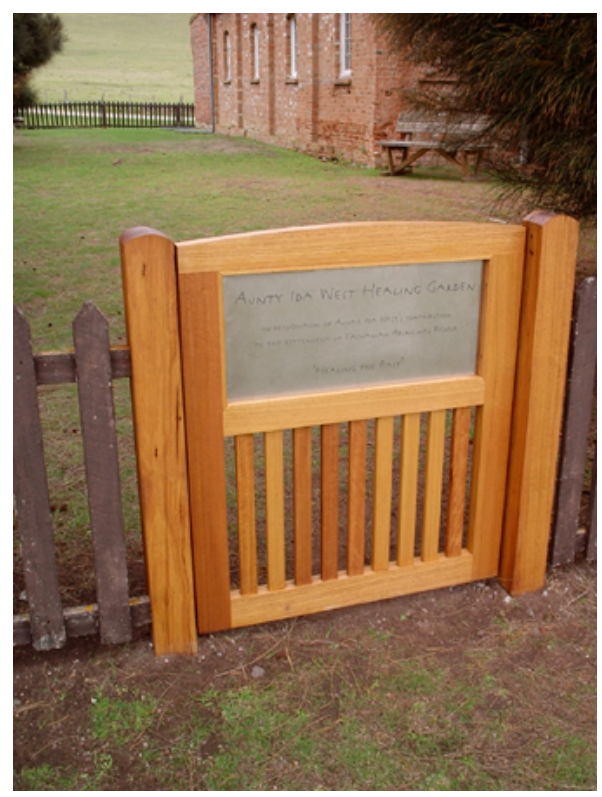


In terms of creating an effect of intimacy, the concept of a garden, with a table and benches, is particularly effective as these are generally places of rest and contemplation. Perhaps the site can serve two purposes. Perhaps it can be an intimate, personal memorial and an educative site about Australia's shared history. Additional interpretation could be given either inside or near the chapel. For example, small unobtrusive signs low to the ground outside the garden would be unlikely to intrude on the atmosphere created inside the garden, but would provide an important re-interpretation of a nationally significant site. It will be instructive to see whether the memorial garden and interpretation of the broader historic site are expanded at Wybalenna. Whether more is done could well depend on what the community decides should be the purpose of the site. The process of healing the past can be a personal or collective experience.

\section{CONCLUSION}

All cultural groups deserve the right to memorialise. For Indigenous people, the creation of memorials of which they have ownership, and feel attached to, can provide a focus for celebration, for hope and for dealing with some of the darker aspects of the Australian past. This article has highlighted some trends in the ways in which Indigenous Australians are memorializing the past. Indigenous people have often been involved in reinterpreting existing monuments so that they become more inclusive of other perspectives of the past as exemplified in the Explorer's Monument in Fremantle. Gardens are often a desired form of memorial for Indigenous people, particularly for sensitive issues that create a need for reflection and space, such as the 'Stolen Generations Memorial' at Mount Annan Botanic Gardens and Wybalenna - or other forms of 'natural' memorials such as the Myall Creek Memorial, which utilises boulders and a scenic rural vista to help the visitor contemplate the past.

When discussing the types of memorials that Indigenous people are creating, the purpose of the memorial is important. Memorials whose primary role is to celebrate the Aboriginal past or to educate non-Indigenous Australians may often adopt 
a 'European' style - such as Warriu Park, the Nicholls memorial and the proposed 'Two Warriors' memorial at Botany Bay

National Park. Memorials which primarily facilitate Aboriginal communities to reflect on the past and not to educate others such as the Aunty Ida West Healing Garden and Memorial Gate at Wybalenna - may take a more natural, reflective form such as a garden.

It is easy to assume that there are particular, culturally appropriate ways in which Indigenous Australians memorialise the past. The number of memorials to the Aboriginal past which utilise natural elements, and the recurrence of controversy with 'non-natural' Aboriginal memorials, add false support to this assumption. Whilst the use of natural materials and natural landscape settings are often harnessed in Aboriginal memorials, Indigenous people and others who memorialise the Aboriginal past do not restrict themselves to this style. Moreover, the role and the meaning attached to these other memorials are facilitated in part by their style. The bronze statues of the Nicholls memorial, for example, are an embodiment of the strength and importance of these people.

The Warriu Park statues are even more conceptually and practically illustrative. They have a resonance for the community who created them, irrespective of the response that outsiders may have to the statues. For local Aboriginal people the statues are representative of their community's resilience. Care must be taken to ensure conceptual restrictions are not imposed on the ways in which Indigenous people can memorialise the past.

The Meeting Place Precinct, including Captain Cook's Landing Place, which was used to open out the exploration at the start of this article, is a contentious heritage site. Even here, however, there is evidence that heritage management can be linked to a more open-minded understanding of memorials. As one stakeholder at the site acknowledged, cultural change is a normal process in all social and religious groups. ${ }^{51}$ Aboriginal people can adopt ways of representing themselves and their history without it being seen as a collapse of their culture. Another stakeholder also noted that the Meeting Place Precinct Master Plan was a working document and that there was certainly 'potential for this type of representation [that is, a 
'Two Warriors' statue] if there was a strong push from the community'. ${ }^{52}$

Non-Indigenous people can often initiate or be the primary drivers of the establishment of memorials to the Aboriginal past. When this is the case, appropriate consultation with relevant Indigenous people is crucial to ensure that the memorial contains Indigenous perspectives and is sensitive to the Indigenous communities' wishes. In this spirit, consultation should occur earlier rather than later. This will help to prevent situations such as the animosity over the 'Separation slivers' at Reconciliation Place, where the Stolen Generations memorials had to fit into the model already determined for Reconciliation Place. Similarly, genuine consultation is about listening to what the community desires and not overriding community wishes because of narrow interpretations of what constitutes an appropriate Aboriginal memorial.

There is great variation in the form and nature of memorials to the Aboriginal past. Indigenous people are creating their own ways to memorialise the past that are appropriate to them, and these may or may not feature socalled 'European' styles of memorialisation. What constitutes Aboriginal heritage, and the ways in which Indigenous people think about the past, will - like the ideas of any group of people - change over time, place and social context. There should be no imposed restrictions on the way that Indigenous people memorialise the Aboriginal past. Just as Aboriginal history and heritage are broad, covering the whole span from the Dreaming to the present day, so too are the ways in which Indigenous people are choosing to commemorate their past.

\section{ENDNOTES}

${ }^{1}$ See, for example, Chilla Bulbeck, 'Australian history set in concrete' in Journal of Australian Studies, vol 28, no 3, 1991, pp3-6.

${ }^{2}$ Keith Windschuttle, Postmodernism and the Fabrication of Aboriginal History (Online, 2007). Available: http://www.sydneyline.com/Postmodernism\%20and\%20Fabricatio n.htm (Accessed 5 January 2008).

3 ibid. 
${ }^{4}$ Bronwyn Batten, 'From Pre-history to History: Shared Perspectives in Australian Heritage Interpretation', PhD Thesis, Macquarie University, 2005.

${ }^{5}$ J. Stephens, Review of the book by K. S. Inglis, Sacred Places: War Memorials in the Australian Landscape, Carlton, Melbourne University Press, 2005, (Online, 2006). Available: http:/ / www.apinetwork.com/cgi-bin/reviews/print.cgi? $\mathrm{n}=0552851908$ (Accessed 5 Jan 2008).

${ }^{6}$ Of course there are some exceptions to this including early memorials to Indigenous Australians, however as a general trend the statement is valid. For further discussion on this see Bronwyn Batten, 'Monuments, Memorials and the Presentation of the Indigenous Past', Public History Review, vol 11, 2004, pp100-121.

${ }^{7}$ NSW National Parks and Wildlife Service, 'The Meeting Place Precinct Master Plan Botany Bay National Park', Kurnell (Online, 2003). Available:

http:// www.nationalparks.nsw.gov.au/PDFs/botany bay masterp lan.pdf (Accessed 5 June 2003) pp79-81.

${ }^{8}$ Batten, 'From Pre-history', p178.

${ }^{9}$ NSW National Parks and Wildlife Service, 'The Emmting Place', p58.

${ }^{10}$ NSW National Parks and Wildlife Service, 'Meeting Place Precinct Draft Master Plan - Botany Bay National Park, Kurnell NSW National Parks and Wildlife Service, 2003, p47.

${ }^{11}$ NSW National Parks and Wildlife Service, 'The Meeting Place', p76.

${ }^{12}$ NSW Department of Environment and Conservation, 'Aboriginal People, the Environment and Conservation: Principles to incorporate the rights and interests of Aboriginal people into the work of the Department of Environment and Conservation NSW', The Department, 2006.

${ }^{13}$ NSW Department of Aboriginal Affairs, 'Stolen Generations Memorial opened at Mt Annan Botanic Garden' (Online, 2007). Available: http:// www.daa.nsw.gov.au/news/30.html (Accessed 5 January 2008).

${ }^{14}$ Botanic Gardens Trust, 'Stolen Generations Memorial' (Online). Available: http://www.rbgsyd.nsw.gov.au/welcome to bgt/mount annan b otanic garden/the garden/buildings and art\#sto (Accessed 5 Jananuary 2008).

${ }^{15}$ P. Cuneo, 'Stolen Generations memorial at Mount Annan Botanic Garden', in Bush Telegraph Magazine (Online, 2006). Available: http:// www.dpi.nsw.gov.au/aboutus/news/bush-telegraphmagazine/winter-2006/stolen-generations-memorial (Accessed 5 January 2008).

${ }^{16}$ National Capital Authority, 'Reconciliation Place' (Online, 2006). Available: http://www.nationalcapital.gov.au/downloads/enhancing and $\mathrm{m}$ aintaining/Reconciliation Place PressRelease.pdf (Accessed 5 January 2008).

${ }^{17}$ National Capital Authority, 'Reconciliation Place: A lasting symbol of our shared journey' (Online). Available: 
http:/ / www.nationalcapital.gov.au/downloads/visiting/reconcilia tion place/Reconciliation\%20Place A lasting symbol of our share d journey.pdf (Accessed 5 January 2008).

${ }^{18} \mathrm{~J}$. Brown and A. N. Kinnear, 'Consultations and Reconciliation Place' (Online, 2002). Available:

http:/ / www.alphalink.com.au/ rez/Journey/ consult.htm (Accessed 19 August 2003), p1.

${ }^{19}$ ibid, p3.

${ }^{20}$ Wikipedia, 'Yagan' (Online, 2008). Available: http:/ / en.wikipedia.org/wiki/Yagan (Accessed 29 May 2008).

${ }^{21}$ ibid.

${ }^{22}$ Stuart Rintoul, 'Statue Salutes a Champion on Field and off in The Australian' (Online, 2007). Available:

http:/ / www.theaustralian.news.com.au/story / 0,25197,228967925012432,00.html (Accessed 29 May 2008).

${ }^{23}$ Bronwyn Lawton, 'Understanding Aboriginal Perspectives of History and Heritage in Wyndham, Western Australia', Honours Thesis, Macquarie University, 2001. Note: Lawton is the maiden name of Bronwyn Batten, the co-author of this paper.

${ }^{24}$ ibid, p94.

${ }^{25}$ Ibid.

${ }^{26}$ Wikipedia, 'Douglas Nicholls' (Online, 2008). Available: http:/ / en.wikipedia.org/wiki/Douglas_Nicholls (Accessed 30 May 2008).

${ }^{27}$ City of Melbourne, 'Sir Douglas and Lady Gladys Nicholls Memorial' (Online, 2008). Available: http:/ / www.melbourne.vic.gov.au/info.cfm?top $=251 \& p g=2045$ (Accessed 30 may 2008).

${ }^{28}$ Rintoul, op cit.

${ }^{29}$ City of Melbourne,' Environment Committee Report: Memorial Statues to Pastor Sir Doug and Lady Gladys Nicholls', (Online, 2006). Available:

http:// www.melbourne.vic.gov.au/opm/bc/CTEE/meetings/EC 34 200605160700.pdf (Accessed 30 May 2008)

${ }^{30}$ Sue-Anne Ware, 'Contemporary Anti-Memorials and National Identity in the Victorian Landscape', Journal of Australian Studies, no $81,2004, \mathrm{p} 122$.

${ }^{31}$ ibid, p123.

${ }^{32}$ Batten, 'Monument, Memorials'.

${ }^{33}$ The Public Action Project, 'Unmasking the Monument: The Other Side of the Pioneer Myth', in The Murdoch Ethos: Essays in Australian History in Honour of Foundation Professor Geoffrey Bolton, Murdoch University Press, Perth, 1989, p222.

${ }^{34}$ ibid, p228.

${ }^{35}$ The Public Action Project, 'Unmasking the Monument', p229.

${ }^{36}$ Chilla Bulbeck, 'The Stone Laurel: Of Race, Gender and Class in Australian Memorials', Institute for Cultural Policy Studies, Division of Humanities, Griffith University, 1988, p10.

${ }^{37}$ Ware, op cit, pp132; 123. 
${ }^{38}$ ibid, p127; 129.

${ }^{39}$ Bronwyn Batten, 'The Myall Creek Memorial - History, Identity and Reconciliation', forthcoming in William Logan and Keir Reeves (eds), Places of Pain and Shame: Dealing with 'Difficult' Heritage, Routledge.

${ }^{40}$ P. FitzSimons quoted in P. Stewart, Demons at Dusk, Sid Harta Publisher, Hartwell, Victoria, 2007, piv.

${ }^{41}$ ibid, piii.

${ }^{42} \mathrm{~J}$. Mulcair, 'Look Back in Sorrow', The Leader, 30 August 2007.

${ }^{43}$ Jesuit Publications, 'The Myall Creek Memorial' in Madonna, September/October (Online, 2003). Available: http:// www.madonnamagazine.com.au/articles/0309pike.html (Accessed 10 December 2004).

${ }^{44}$ T. Stubbins and P. Smith, 'The Myall Creek Massacre: It's History, It's Memorial and the Opening Ceremony', Bingara, The Myall Creek Memorial Committee, 2001, p11.

${ }^{45}$ ibid, pp11-12.

${ }^{46}$ Stubbins and Smith, op cit.

${ }^{47}$ ibid.

${ }^{48}$ Batten, 'The Myall Creek Memorial'.

${ }^{49}$ Batten, B. 2005, op cit, p92.

${ }^{50}$ Women Tasmania, 2004. Significant Tasmanian Women: Ida West, (Online). Available: http://www.women.tas.gov.au/siginificantwomen/search/ida we st.html (Accessed 25 June 2004)

${ }^{51}$ Batten, 'From Pre-history', p180.

52 ibid. 